\title{
THE USE OF CODE SWITCHING BY ENGLISH LECTURERS OF ENGLISH DEPARTMENT UNIVERSITAS PAMULANG
}

\author{
Sarita Merilia \\ dosen01710@unpam.ac.id \\ Universitas Pamulang (UNPAM), Pamulang, Tangerang Selatan, Banten, Indonesia \\ Ismi Adinda \\ dosen00602@unpam.ac.id \\ Universitas Pamulang (UNPAM), Pamulang, Tangerang Selatan, Banten, Indonesia
}

\begin{abstract}
This research aims at investigating types of code switching used by lecturers and what are the reasons among English lecturers in English Department of Universitas Pamulang. Out of 70 lecturers of the population, 33 lecturers were chosen as the samples based on the random sampling. The data in this study were obtained through questionnaires (open-ended questionnaire). This study revealed that tag switching is a type of code switching which is mostly used by the English lecturers. Then Intra sentential is the second type which is used by the lecturers and the last is inter sentential. Lecturers identified a number of reasons of using code switching in classrooms: teaching new students, making students to understand the material conveyed, avoid the miss understand toward the material, no appropriate word, creating effective communication and other problems.
\end{abstract}

Keywords: code switching, type of code switching, reason of using ode switching 


\section{INTRODUCTION}

Communication problem experienced by educators or education practitioner varies. It takes place whether in formal or informal education. For example, in formal education, communication problem is experienced by both teacher and students whether in classrooms or outside the classrooms. As mention above, there are some problems they faced in using language as a communication tool. One of them is the ability to understand the language. This commonly happens in a language learning classroom, such as English learning.

To understand the language, both teachers and students used some strategies, such as using gesture, or mix and switch the language to the native language. These phenomena are called by code-switching and code-mixing. Switching languages commonly happened in the classroom context. Teachers and students do the code-switching with many reasons, such as explain complex topics, to explain and clarify teaching instruction and activities, to create a warm environment between the teachers and students, etc. However, the inability to understand the language is not only the reason for teachers or student to do codeswitching or code-mixing. Novianti (2013) in her research found that one of the most reason for people to do code-switching is a lexical reason. Some expressions cannot be expressed in a target language. The lack of vocabulary is also another reason for codeswitching. To emphasize the message and to clarify the content are found as the reasons for code-switching done by American students of Darmasiswa program (Retnawati \& Mujiyanto, 2015).

Code-switching may happen when people want to speak and they require it (Wardhaugh, 2006). Further, Holmes (2001) stated that people in some communities uses another language dealing with the situation demanding them to convey the words. Codeswitching occurs when people take conversations in various situations whether formal or informal. When there are situation changes, it easy to explain by switch the language, such as it for the new arrival person who arrives at a new place to explain the situation. While in the classroom context, code-switching seems often happen. Xu Qing (2010) defines in classrooms context, code-exchanging is a sort of plain phonetic decision and fill in as one of encouraging procedure utilized by instructors to accomplish learning objectives. Code-switching is not only switching between two languages but also involve some languages. It depends on how many languages can people speak.

Regarding the explanations above, it is needed to conduct a research to explore the use of codeswitching by lecturers in English Department. This research aims at observing the types of codeswitching, the languages used, and the reasons for using code-switching in communicating at classrooms. Giving new relevant knowledge in code-switching and related theory to this study are the expectation in this research.

\section{THEORETICAL FRAMEWORK}

\section{Sociolinguistics}

Linguistics is the logical think about of dialect. The utilize of dialect is one of the characterizing characteristics of human being, and it is fundamental component for the method of communication that hold society together. Phonetics is the field that relates to numerous other human exercises that are intensely subordinate on language. A dialect could be a complex framework of symbols, or signs, that are shared by individuals of

a community. It'll be valuable to consider other signs that we know and how we respond them (Kreidler,1998:20).

Whereas, sociolinguistics may

be a creating subfield of phonetics which takes discourse variety as its center, seeing variety or it social setting. Sociolinguistics is concerned with the relationship between such social components and phonetics variety (Nancy Parrot Hickerson :1980; 81).

Sociolinguistics is the think about of the characteristics of dialect assortments, the characteristics of their capacities, and the characteristics of their speakers as these three continually connected, alter and alter one another inside a speech community (Fishman: 1972).

Sociolinguistics is the ponder that's concerned with exploring the relationship between dialect and society with the objective of a better understanding of the structure of dialect and of how dialects work in communication (Wardhough, $1986: 12$ ).

The study that's concerned with the relationship between dialect and the setting in which it is utilized. In other words, it thinks about the relationship between dialect and society. It clarifies we people speak in an unexpected way in 
numerous social settings. It talks about the social functions of dialect and the ways it is utilized to communicate social meaning. All of the themes gives a parcel of data approximately the di alect works, as well as almost the social connections in a community, and the way individuals flag perspectives of their social character through their dialect. (Jenet Holmes, 2001).

"Sociolinguistics is think about of dialect in connection to society" (Hudson 1996; 1).

"Sociolinguistic is the field that thinks about the connection between dialect and society, between the employments of dialect and the social structure, in which the clients of dialect live" (Spolsky: 1998; 3).

"The consider that's concerned with the interaction of dialect and setting" (Carol M. Eastman, 1975 ; 113).

"The sociolinguist's point is to move towards a hypothesis which gives a persuaded account of the way dialect is utilized in a community, and of the choices individuals make when they utilize dialect." (Janet Holmes (1992; 16).

\section{Code Switching}

Hymes (1974) defines code-switching as "a common term for alternative use of two or more languages, varieties of a language or even speech styles". Bokamba (1989) defines code-switching is the mixing of words, phrases and sentences from two distinct grammatical (sub) systems across sentence boundaries within the same speech event.

Code switching is changing back and forth between two language varieties especially in a single conversation (Trask and Stockwell:2007) ."Meisel (1994) states that:

Hymes (1974) characterizes code-switching as "a common term for elective utilize of two or more dialects, assortments ofa dialect or indeed disco urse styles". Bokamba (1989) characterizes codeswitching is the blending of words, expressions and sentencesfrom

two unmistakable syntactic (sub) frameworks over se ntence boundaries inside the same discourse event.
Code switching is changing back and forward betweentwo dialect assortments particula rly in a single discussion (Trask and Stockwell:2007).” Meisel (1994) states that:

"Code switvhing is the capacity to choose the dialect agreeing to the interlocutor, the situational setting, the subject of discussion, and so forward,andto alter dialects inside an associatio ns arrangement in agreement with sociolinguistic rulesandwithout abusing particular syntactic const raints."

Hypothesis that has enormous affect in social and pragmatics perspectives of code exchanging is the 'markedness' hypothesis of code exchanging. The Markedness Demonstrate is proposed by MyersScotton (2006: 159):

"The Markedness Model tries to set up a principled strategy that both speakers and audience members utilize to judge any phonetic choice that they might make or listen as more or less checked, given the interaction in which it happens. The method that's utilized is this: As portion of our communicative competence, and based on involvement in our communities, we create a sense that there's a continuum of choices for a specific interaction sort that are considered unmarked."

The marked versus unmarked distinction used by the Markedness Model as a theoretical construct to explain the social and psychological motivations for making one code choice over another. Many code switching researchers have distinguished between 'unmarked' language choices as the language used that would be expected in the context, and 'marked' choices as the language used that would not normally be expected. Myers-Scotton has distinguished the Markedness Model (as cited in Mesthrie, Swann, Deumert, \& Leap, 2000, 166) become four code switching patterns:

The stamped versus

unmarked refinement utilized by the Markedness Demonstrate asa hypothetical build to cl arify thesocialand mental inspirations for making one 
codechoiceoveranother. Numerous code exchanging a nalysts have recognized between 'unmarked' dialect c hoices as the dialect utilized that would be anticipated within the setting, and 'marked' choices as

the dialect utilized thatwouldnot regularly be anticipa ted.

Myers-Scotton

has recognized the Markedness Demonstrate (as cited in Mesthrie, Swann, Deumert, \& Jump, 2000, 166) ended up four code switching designs:

1. Code-switching as a arrangement of unmarked choices between distinctive dialects. Codeswitching may be related with a arrangement of unmarked choices when viewpoints of the setting such as a alter in theme or within

the individual tended to make a distinctive dialect assortment more appropriate.

2. Code-switching itself as an unmarked choice. It is the utilize of both dialects together that's significant, drawings on the affiliations of both dialects and ordering double characte rs.

3. Code-switching as a stamped choice. Code exchanging is stamped when it does not adjust to

This exchanging is expected designs. extend social separate, used to specific authority.

4. Code-switching as an exploratory choice. Code exchanging may have an exploratory work when the unmarked choice is uncertain.

\section{a. Tag Switching}

Tags-

witching includes the inclusion of a tag in one dialect into is something an expression which elsecompletely within enct, e. g. you know, I cruel, etc. , to require a few English cases Agreeing to Romaine (1995: 122). For illustration: 'I'm satisfied to see you're getting Bewegungsmelder, ja' (Security light, yes) (Stockwell, 2007).

\section{b. Inter-sentential Code Switching}

Intersentential switching, in which a alter of dialect happens at sentence levels, where each clause or sentence is in one dialect or the other. Intersentential switching includes a switch at clause or sentence boundaries, where each clause or sentence is in one dialect or another. In expansion, the speaker is additionally as a rule oblivious of the exchanging. In case intersentential switching can be thought of as requiring more noteworthy familiarity in both dialects than tag exchanging since major parcels of the expression must acclimate to the rules of both dialects (Romaine 1995 : 122). An example of inter-sentential code switching (Stockwell, 2007:48): 'We're attending to Nicky's House at nine and possibly to the bomb [a club] a short time later. (Brief delay). Kristina bleibt allerdings zu hause sie muss noch arbeiten' (Tragically Kristina is remaining at domestic since she still needs to do a few work). The example appears in the event that the discussion switches at a sentence boundary, checked with a brief delay. At the point where the subject changes to allude the speaker's German housemate.

\section{c. Intra-sentential Code Switching} Intrasentential switching includes, oste nsibly, the most prominent syntactic chance, and may be dodged by all but the foremost familiar bilinguals. Agreeing to Romaine (1995: 123). In intra-sentential code switching, the hazard of jeopardizing the syntactic run the show is much higher than the past two. As expressed by Christopher Barenberg in Stockwell (2007: 48), this exchanging is requiring the most prominent degree of common bilingual capability which might not have existed in this brief discourse community. For example: What's so amusing? Come, be great. Something else, yu bai go long kot. 'What's so amusing? Come, be great. Something else, you'll go to court (Romaine, 1995: 123). 


\section{RESEARCH METHOD}

The current research employed a qualitative study by including survey items aimed at describing what type of code switching used by the English lecturers. Next, the study also elaborated the respondents reasons of using code-switching in classroom.

The participants of this study were lecturers of English Department at Faculty of Letter of Universitas Pamulang. Out of 70 lecturers of the population, 33 lecturers had been chosen as the samples based on the random sampling.

In order to gather the required data, the researcher gave a questionnaire to the research sample. The questionnaire was online questionnaire. The lecturers were shared the link and filled the questionnaire.

In this research, the researcher used questionnaire in order to collect to collect the data. The questionnaire asked about how the lecturers use code switching in classrooms and what reason they do code switching.

After collecting the data, the researcher categorized the data based on the answer of the research question. The data that had been categorized were explained based on the literature and context.

\section{RESULLT AND DISCUSSION}

This section focuses on the discussion of the research findings. The finding is to answer research question of the types of code switching and the reason $f$ using code switching in classrooms.

\section{Types of Code Switching}

According to Poplack (1980:230) three types of code switching based appear on the idea of juncture where language change happens; inter-sentential code switching, tag switching, and intra-sentential code switching. From the questionnaire, researchers found the data as below.

\section{Table 1}

The types of code switching occurred by lecturers

\begin{tabular}{|c|c|c|}
\hline & $\begin{array}{l}\text { Type of code } \\
\text { switching }\end{array}$ \\
\hline
\end{tabular}

\begin{tabular}{|c|c|c|c|c|}
\hline $\begin{array}{l}\text { N } \\
\text { O. }\end{array}$ & $\begin{array}{l}\text { Total Lecturers } \\
\text { Using } \\
\text { Code } \\
\text { Switching }\end{array}$ & $\begin{array}{c}\text { Int } \\
\text { ra } \\
\text { sen } \\
\text { ten } \\
\text { tial } \\
\text { co } \\
\text { de } \\
\text { Swi } \\
\text { tchi } \\
\text { ng }\end{array}$ & $\begin{array}{c}\text { Int } \\
\text { er } \\
\text { sen } \\
\text { ten } \\
\text { tial } \\
\text { co } \\
\text { de } \\
\text { swi } \\
\text { tchi } \\
\text { ng }\end{array}$ & $\begin{array}{l}\text { Tag } \\
\text { switc } \\
\text { hing }\end{array}$ \\
\hline & $\begin{array}{l}3 \\
0\end{array}$ & $\begin{array}{l}12 \\
\text { tim } \\
\text { es }\end{array}$ & $\begin{array}{c}4 \\
\text { tim } \\
\text { es }\end{array}$ & $\begin{array}{c}14 \\
\text { times }\end{array}$ \\
\hline & $\begin{array}{l}\mathbf{T} \\
\mathbf{o} \\
\mathbf{t} \\
\mathbf{a} \\
\mathbf{l}\end{array}$ & $40 \%$ & $\begin{array}{l}13.33 \\
\%\end{array}$ & $\begin{array}{l}46 \\
67 \\
\%\end{array}$ \\
\hline
\end{tabular}

From table one, there are 30 lecturers using code switching in teaching in the classroom; $40 \%$ used intra sentential code switching, $13,33 \%$ used intersentential code switching and $46,67 \%$ use tag switching. The researcher concludes that the code-switching type mostly occured in this research is tag switching. Inter sentential is the following type of code-switching, and intersentential is the lowest of used.

From the data of questionnaire, reserchers found that there were 2 languages, English and Indonesian languages used as code switching by English department lecturers. Researchers didn't find either any local nor otheh foreign language. In case students of Unpam come from various regions that understand national language.

\section{The reason of using code-switching.}

As the interaction between Indonesian students and lecturer take place at classroom, the use of codeswitching repeated occurs. Many reasons why they use code switching. To answer this second research questions, the researchers had spread an open questionnaire. Located on the result finding which spread to lecturers at English Letter Faculty, some reasons which were categorized were found as follows: 
Tabel 2. Categories of the data

\begin{tabular}{|c|c|}
\hline $\begin{array}{l}\text { Reason of Using Code } \\
\text { Switching }\end{array}$ & \\
\hline No appropriate word & Data 1 \\
\hline Giving emphasize & Data 2 \\
\hline Teaching new students & Data 3 \\
\hline $\begin{array}{l}\text { To create communicative } \\
\text { communication }\end{array}$ & Data 4 \\
\hline $\begin{array}{l}\text { To easier students' } \\
\text { understanding toward the } \\
\text { material }\end{array}$ & Data 5 \\
\hline $\begin{array}{l}\text { To avoid students' miss } \\
\text { understanding toward the } \\
\text { explanation }\end{array}$ & Data 6 \\
\hline $\begin{array}{l}\text { To create friendly and warm } \\
\text { study environment }\end{array}$ & Data 7 \\
\hline Other & Data 8 \\
\hline
\end{tabular}

\section{Picture 1. Data Result}

\section{Apa alasan Anda melakukan code...hasa Inggris? 33 responses}

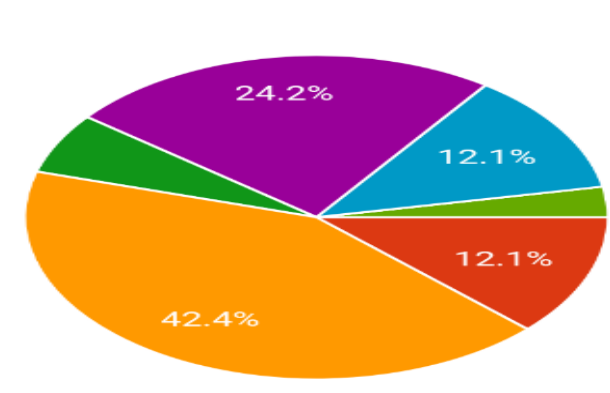

Data 1

No appropriate word
Based on the result, it is found that only $6 \%$ of lecturer who think that no appropriate words that can use to explain the material. It makes them to switch the language into Bahasa Indonesia. They think when they switch the language the message is achieved by the students correctly. Even though, substitute the language means that the students do not get the appropriate English term for the topic they study.

\section{Data 2}

\section{Giving emphasize}

Only $12,1 \%$ lecturers who use code-switching to give the emphasize. Even though, most students understand the topic explained some time they will not focus on the important part. To this reason, lecturers switch the language to emphasize the important words, sentence or topic. With switching the language to emphasize the important part, it is hope the message further aim of learning will be achieved.

\section{Data 3}

\section{Teaching new students}

New students come from plural background. It means they have various ability on understanding English. Not all students who take English as their major will automatically able to communicate in English. Some of them need help to acquire the learning output. For this reason, $42,4 \%$ lecturers do code-switching while teaching in the classrooms.

\section{$\underline{\text { Data } 4}$}

\section{To create communicative communication}

Classroom is the place where students-lecturers communication frequently happen. To achieve the aim of learning, lecturers and students have to create communicative communication whether on learning process, daily communication, in-classroom or outclassroom. Sometime, lecturers find struggle on creating communicative communication while doing learning process. Based on the research finding, it is determined that code switching use to overcome the problem.

\section{$\underline{\text { Data } 5}$}

To easier students' understanding toward the material 
$24,2 \%$ lecturers think when they switch the language the students will assist the students to apprehend the material. People will feel free to communicate when they use their own language. They will express and understand messages easily.

\section{Data 6}

To avoid students' miss understanding toward the explanation

Based on the data resut, $12,1 \%$ lecturers recognize that sometime students miss understand toward what lecturers explained. To overcome the problem, students need to be explained by using another words or switch the language.

\section{$\underline{\text { Data } 7}$}

To create friendly and warm study environment

It is like a new comer who uses their own language to communicate, people who involve will feel insecure and confuse. It is also happening when conversation take place in the classrooms. It will be one-side communication or the students feel uncomfortable. However, based on the data result, it is only 1 lecturer who think switch the language is needed to create friendly and warm study environment.

\section{Data 8}

\section{Other reason}

Beside the reason above, the researcher found another reason mentioned by lecturers. Switching the language is helpful for students to remember vocabularies. Knowing the translation is a strategy to remember a word. Lecturer explained the meaning of the words in another language or they only translate the word into Bahasa Indonesia.

\section{CONCLUSION AND SUGGESTION}

In the light of the findings of the present study and the discussion based on these findings, these are the conclusion and suggestion: (1) almost all of english department lecturers used code switching; (2) tag switching was the most dominant type of code switching which has been found in this research; (3) there were 2 languages used in lecturing process in using code switching; (4) there are many reasons of why lecturers do code-switching such as giving emphasize, could not find appropriate term to convey the message, teaching new students, to avoid miss understanding toward the material.

The researchers suggest some point based on the result above that (1) researcher suggest for next studies to research another literary work and another scope of research; (2) for lecturers, they can use code switching in order to help language learning process, such as to convey intentions clearly, convey words or sentences that cannot be presented by English, to give emphasize important word and to avoid misunderstanding toward the material; (3) students can switch languages in order to easier understanding what lecturers conveyed, clarified lecturers' instructions; (4) readers can also use code switching in their daily life to easier communication.

\section{REFERENCES}

Chaer, A. \& Agustina, L. (1995). Sosiolinguistik: Perkenalan Awal. Jakarta: PT Rineka Cipta.

Fromkin, V. (1981). An Introduction to Language. Japan: Holt, Rinehart and Winston,

Holmes, J. (2001). An Introduction to Sociolinguistics (2 nd ed). London: Longman.

Hudson, R.A. (1996). Sociolinguistics. Cambridge: Cambridge University Press.

Ralph, F. (2006). An Introduction to Languages and Linguistics, New York: CambridgeUniversity Press,.

Retnawati, S. \& Mujiyanto, Y. (2015). Code Switching Used in Conversations by An American Student of the Darmasiswa Program. Jurnal of Language and Literature, $X, 29-35$.

Ruslan,M. (2003). Computational Linguistics, New York: Oxford,.

Spolsky, B. (1998). Sociolinguistics. Oxford: Oxford University Press. 
Stewart, T,W. (2001). Language Files. Ohio: The Ohio State University,

Wardhough, R. (2006). An Introduction to sociolinguistics, $5^{\text {th }} \mathrm{ed}$. Oxford \& Malden, MA: Blackwell.

Whemier, S. (2008). Oxford Advanced Learner's Dictionary 7th Edition. Oxford: Oxford University Press.

Xu Qing. (2010). To Switch or Not to Switch: xamine the Code Switching Practices of Teachers of Non-English Majo. Canadian Social Science. Vol. 6, No. 4, 2010, pp.109-113. 